\title{
Saylor, Ryan \\ State Building in Boom Times: Commodities and Coalitions in Latin America and Africa
}

Helder Ferreira do Vale*

Oxford: Oxford University Press, 2014. 244 p.

The historical factors which underlie the building of stronger public institutions have been systematically studied across many disciplines. Yet, the historical conditions and processes that have made certain public institutions stronger in some countries, but not in others, remain little understood. State Building in Boom Times sheds new light on this issue by analyzing the conditions of state building beyond Europe. In so doing, the book highlights the role of commodity export sectors in strengthening public institutions during resource booms.

Ryan Saylor attempts to understand state capacity augmentation in moments of commodity export surge by engaging in a historical comparison of six countries - Argentina, Chile, Colombia, Ghana, Mauritius, and Nigeria. The book focuses on two critical elements: coalitions between economic and political actors, and the delivery of public goods (e.g., territorial pacification, transportation, reduction of capital transaction costs).

The book argues that countries which favored the formation of coalitions between political and economic elites during boom times thereby created strong incentives for the ruling elites to expand the provision of public goods. Saylor considers commodity booms to be disruptive to the status quo, as they generate profit for certain economic actors who will then threaten the political hegemony of the ruling elites by demanding the provision of additional public goods.

In Saylor's analysis, the creation of boom time elite coalitions determined the variation of state building across his six countries. Argentina, Chile and Mauritius provide the most successful stories of state building in Latin America

\footnotetext{
* Hankuk University of Foreign Studies, Seul, Republic of Korea. helderdovale@gmail.com <https:// orcid.org/0000-0002-4993-7932>
} 
and Africa. These were countries where pro-state building coalitions were successfully formed between the ruling political elites and the emerging export commodity actors for the distribution of the gains of the commodity boom. The provision of public goods was one of the main results of this elite pact.

By contrast, Colombia, Ghana and Nigeria did not succeed in state building largely because the newly economically empowered exporters, who attempted to maintain high accumulation of profit by acquiring political power, failed to align themselves with the ruling political elites. For their part, the political elites in these countries believed the commodity exporters did not represent a credible and durable threat to their political position, and therefore they did not respond to the demands coming from the export sectors benefiting from the boom time.

In Chile, the export of wheat and copper flourished from 1848 to 1883. Chile originally formed its core political alliance in the northern-central region, to the detriment of other parts of the country. The politically marginalized regions used the boom to challenge the status quo by demanding that the state provide public goods, such as railroads, to reduce transportation costs and support the extraction of further commodities. After hesitating to accede to these demands, the Chilean leadership finally subsidized the construction of railroads, which simultaneously allowed the state to territorially penetrate remote regions of the country.

The case of Argentina followed a similar pattern. Between 1852 and 1886, the wool export sector increased its economic leverage, requiring the expansion of sheep ranches beyond Buenos Aires province, where political and economic power had traditionally been concentrated. The littoral and northern provinces, where new sheep ranches were created, disrupted the territorial balance of power in Argentina, forcing the ruling elites in Buenos Aires to expand the provision of public goods to these areas by establishing railroads and a new banking system.

Similar to Argentina and Chile, between 1825-1895 Mauritius expanded state capacity under a boom time coalition in which sugar exporters consolidated themselves as the dominant ruling elite without much opposition from other elite groups. This ruling coalition managed to expand state capacity in areas that favored the export boom, such as the building of transportation infrastructure, facilitation of credit, and the enactment of coercive labor regulations.

Differently from Argentina and Chile, in Mauritius the central state did not institutionalize the boom time balance of power at the local level. This happened because while in Mauritius the sugar exporters were the main 
winners of commodity booms, in Argentina and Chile there were several competing groups of exporters that benefited from the export boom. In the latter cases, with the purpose of containing local elite rivalry, the central state created institutions at the local level, referred to as "unmediated institutions." These institutions ultimately strengthened state capacity and replaced societal notables by central level administrators.

The three remaining cases serve as examples of the failure of state building. In Colombia (1880-1905), the ruling elites were not compelled to respond to the demands of the coffee exporters during the commodity boom. Public goods' provision increased only gradually and outside the coffee-exporting regions of the country. Ghana (1945-1966) stands as an example of a shift in the ruling coalition from one based on traditional leadership to an emerging urban elite. This resulted in the marginalization of the cocoa exporters during the export boom. Nigeria (1945-1966) experienced a boom in several commodities, including cocoa, groundnuts and palm oil. However, the exporters of these commodities were incapable of articulating a demand, let alone a threat, to the nationalist ruling coalition, which led to their marginalization.

Among this book's numerous theoretical contributions, it is worth highlighting several in particular. First, it advances a rather innovate proposition of state building by placing the agent-driven demand for public goods from peripheral elites as a central element. Second, the book provides a different perspective on the long-established notion that a country's economic reliance on commodity exports undermines the institutional capacity of the state. Third, the analysis considers marginalized actors as important agents in building coalitions. Fourth, the book identifies the important role of local institutions in the territorial political dynamics once boom time ruling coalitions are formed.

These are important contributions, but the book also presents certain other elements that warrant further discussion. It is important, for instance, to consider the type of states which were being built in these countries. All the states under consideration were non-democratic and captured by powerful elites, which are important aspects ignored by Saylor. Saylor argues that in order to maintain a coalition, it was necessary for actors to make use of economic, political and cultural side-payments, which were benefits granted as a compensation for loyalty. Despite highlighting this crucial dynamic, Saylor does not sufficiently explore the negative consequences of side-payments as corrupt practices that might have impacted in the development of state capacity.

Saylor's approach to the historical evolution of institutions also has a tendency to ignore the possibility of changes and reversals in state building, as he 
considers state capacity to remain constant over time. Put differently, in congruence with the literature on state (Soifer, 2016), Saylor interprets state building as a linear historical process without much possibility of alternative trajectories.

The role of historically-critical junctures is another significant factor overlooked in this book. Considering there were wars in five of these six countries during their respective commodity booms, it would be interesting to know how consequential wars have been to state building. This is all the more important when we recall that peacemaking incentives were created in some countries, while not in others, and that peacemaking and peacekeeping efforts have been shown to affect the process of state building (Kovács, 2019).

A final element of state building in a developing context that Saylor does not consider is the role of social classes - a factor with significant implications for coalition-making (Waldner, 1999). In the specific case of Latin America, there are indications that labor mobilization has contributed to different dimensions of state building (Kurtz, 2013). That said, the question of how social classes contributed to the shaping of coalitions for state building remains largely unanswered.

Despite these criticisms, coalition-making in boom times for the provision of public goods is undoubtedly an innovative perspective that will remain deeply influential for our understanding of state building for years to come.

\section{REFERENCES}

KOVÁCS, Balázs Áron. Peace Infrastructures and State-Building at the Margins. Cham: Palgrave Macmillan, 2019.

KURTZ, Marcus J. Latin American State Building in Comparative Perspective: Social Foundations of Institutional. Cambridge: Cambridge University Press, 2013.

SOIFER, Hillel David. The Development of State Capacity. In: FIORETOS, Orfeo; FALLETI, Tulia G.; SHEINGATE, Adam (ed.). The Oxford Handbook of Historical Institutionalism. New York: Oxford University Press, 2016.

WALDNER, David. State Building and Late Development. Ithaca: Cornell University Press, 1999.

Review received December 15, 2018.

Approved May 11, 2019. 